PIOTR RAŹNIAK

Uniwersytet Pedagogiczny, Kraków, Polska

\title{
Zależność pomiędzy miejscem w międzynarodowych hierarchiach miast a poziomem usług turystycznych
}

\author{
Relation Between the Place \\ in International Hierarchies of Cities \\ and the Level of Tourist Services
}

\begin{abstract}
Streszczenie: W niniejszym opracowaniu przedstawiono poziom rozwoju usług i infrastruktury turystycznej, która może wpływać na oddziaływanie międzynarodowe danego ośrodka. W badaniu wzięto pod uwagę liczbę noclegów udzielonych turystom zagranicznym, wyposażenie obiektów noclegowych w usługi konferencyjne oraz liczbę obiektów noclegowych średniej i wyższej kategorii. Utworzono ranking polskich miast wojewódzkich pod względem poziomu usług i infrastruktury, a następnie odniesiono go do hierarchii miast globalnych, europejskich. Otrzymany ranking zestawiono również z poziomem rozwoju społeczno-ekonomicznego polskich dużych miast. Stwierdzono, iż polskie ośrodki, które cechowały się najlepiej rozwiniętą bazą noclegową średniej i wyższej klasy oraz oferowały szeroki wachlarz usług związanych z organizacją spotkań biznesowych i konferencji, są także najwyżej sklasyfikowane w hierarchiach międzynarodowych. Ponadto nie stwierdzono bezpośredniego związku pomiędzy liczbą ludności danego ośrodka a liczbą turystów zagranicznych odwiedzających dane miasto, czy też poziomem rozwoju infrastruktury i usług turystycznych tych miast.
\end{abstract}

\begin{abstract}
This paper describes the level of development of tourism services and infrastructure, which may affect the international connections of cities. The study takes into account the number of nights spent by foreign tourists, equipment of hotels, accommodation facilities in conference services and the number of accommodation facilities and higher average category. The created ranking of Polish cities which are capitals of the provinces in terms of services and infrastructure is then compared to the hierarchy of global cities, and European cities. The last ranking also lists the level of socio-economic development of Polish cities. It is found that the Polish centers, which are characterized by the best-developed base middle and upper class of accommodation places, and offer a wide range of services related to the organization of business meetings and conferences, are also classified in the highest international hierarchies. In addition, there is no direct relationship between the number of city inhabitants and the number of foreign tourists visiting a city, or the level of development of tourist infrastructure and services these cities.
\end{abstract}

Słowa kluczowe: hierarchie miast; miasta światowe; turystyka biznesowa; usługi turystyczne

Key words: business tourism; hierarchies of cities; tourist services; world cities 


\section{WSTĘP}

We współczesnym globalizującym się świecie firmy prowadzą wymianę handlową na rynkach całego świata. Otwierają przedstawicielstwa i oddziały w nowych miejscach, próbując pozyskać kolejne rynki zbytu. Mimo iż coraz częściej wykorzystywane są w kontaktach media elektroniczne, to wraz z rozszerzaniem się przestrzennym działalności gospodarczej niezbędne są podróże służbowe. W dzisiejszej gospodarce opartej na wiedzy konferencje o zasięgu międzynarodowym są zjawiskiem powszechnym i stały się areną wymiany poglądów, myśli technicznej i idei. Przedsiębiorstwa funkcjonujące na współczesnym, dynamicznie rozwijającym się rynku muszą cechować się innowacyjnością, efektywnością i elastycznością działań. Skutecznym sposobem osiągnięcia przewagi konkurencyjnej coraz częściej staje się wdrażanie innowacji w różnych obszarach funkcjonowania przedsiębiorstwa (Szymańska, 2012a, 2012b, 2012c). Uczestnictwo w konferencjach, kongresach, targach i wystawach (Nowakowska, 2002; Kulbaczewska, Kubicki, 2007), będąc z jednej strony głównym powodem przyjazdów w celach służbowych, jednocześnie przyczynia się do wymiany doświadczenia i myśli technicznej niezbędnej do dalszego rozwoju technologicznego i gospodarczego. Ważnym powodem przyjazdów są również inwestycje pracodawców w szkolenia, podnoszące poziom wiedzy i kapitału społecznego pracowników (Michalak, Warzocha, 2007). Najważniejsze miasta świata skupiają na swym terenie firmy o zasięgu globalnym, są areną działań przemysłu high-tech czy też spotkań o charakterze międzynarodowym. Ponieważ głównym kierunkiem podróży biznesowych są duże miasta (Bartoszewicz i in., 2003), powinny one mieć jak najszerszą ofertę związaną z infrastrukturą noclegową i konferencyjną, która może się przyczynić do ich dalszego rozwoju. Odpowiedni poziom usług i infrastruktury turystycznej może przyciągnąć nowych klientów poszukujących miejsc o odpowiednim standardzie do zorganizowania spotkań biznesowych, zwłaszcza iż w ostatnich latach wzrasta liczba osób przybywających do Polski z zagranicy w celach służbowych (Kulesza, 2008; Kłębek, 2009), choć w początkowym okresie światowego kryzysu gospodarczego zaobserwowano nieznaczny spadek ruchu i popytu turystycznego na świecie (Zdon-Korzeniowska, Rachwał, 2011). Do tego typu działalności niezbędne jest odpowiednie zaplecze związane z usługami i infrastrukturą turystyczną, które najbardziej rozwinięte są w miastach globalnych (Vijver, Derudder, Bassens, Witlox, 2012).

Celem niniejszego opracowania jest określenie poziomu rozwoju usług i infrastruktury turystycznej, który może wpływać na miejsce ośrodka w systemach miast światowych i europejskich. Wzięto pod uwagę polskie miasta wojewódzkie oraz Trójmiasto i konurbację katowicką, jako dwa zespoły nieposiadające jednego dominującego ośrodka miejskiego.

Do ukazania hierarchii miast posłużono się danymi dotyczącymi międzynarodowego ruchu turystycznego, wyposażenia obiektów noclegowych w usługi związane z organizacją spotkań oraz liczby obiektów noclegowych średniej i wyższej klasy $\left(3^{*}, 4^{*}, 5^{*}\right)$. Na ich podstawie stworzono syntetyczny ranking, który porównano z miejscem miast $\mathrm{w}$ rankingach związanych z powiązaniami międzynarodowymi i poziomem rozwoju społeczno-gospodarczego. 


\section{HIERARCHIE MIAST ŚWIATOWYCH}

Jedną z hierarchii miast światowych przedstawili P.J. Taylor i in. (2010), wyróżniając w niej trzy typy: alfa, beta, gamma oraz potencjalne miasta światowe (sufficiency cities). Autorzy wzięli pod uwagę lokalizacje firm należących do sektora kreatywnej wiedzy: rozrachunkowych (accountancy), reklamowych (advertising), konsultingowych (management consultancy), finansowo-bankowych (financial services) i prawniczych (law) w latach 2000, 2004 i 2008. Po przeprowadzeniu analizy 525 miast przedstawiono podział najwyższego typu alfa na: alfa++, alfa+, alfa i alfa-. Do najważniejszych ośrodków na świecie zaliczono Londyn oraz Nowy Jork, które jako jedyne umiejscowiono w typie alfa++ (ryc. 1). Na kolejnych miejscach (typ alfa+) znalazł się Hongkong, Paryż, Singapur, Sydney, Mediolan, Szanghaj i Pekin. Wyraźnie zaznaczył się w latach 2000-2008 duży wzrost znaczenia miast zlokalizowanych w Azji Południowo-Wschodniej: Singapur, Pekin, Hongkong czy też Dżakarta. W omawianym przedziale czasowym traciły natomiast swoje powiązania międzynarodowe ośrodki zlokalizowane w Stanach Zjednoczonych, takie jak Chicago i Los Angeles. Najbardziej negatywne zjawiska zanotowano w San Francisco, które z typu alfa w 2000 roku spadło do typu beta+ w 2008 roku.

Nastąpił także wzrost znaczenia metropolii w krajach rozwijających się (emerging markets), wśród których takie miasta jak: Seul, Moskwa, Bombaj, Buenos Aires i Kuala Lumpur w 2008 roku zostały zakwalifikowane do typu alfa. Należy zauważyć, iż w Warszawie zaliczonej do typu gamma w 1998 roku (Beaverstock, Smith, Taylor, 1999) zdecydowanie wzrosły powiązania globalne i w 2008 roku stolica Polski była najważniejszym miastem w typie alfa-. Jednocześnie w zestawieniu najbardziej globalnych ośrodków brakuje dynamicznie rozwijającego się Berlina. Warto nadmienić, iż z byłych krajów socjalistycznych oprócz Warszawy tylko Budapeszt i Praga zostały sklasyfikowane jako ten sam typ. W badanym okresie zauważono również ogólny wzrost powiązań międzynarodowych we wszystkich typach: alfa++, alfa+, alfa i alfa-. Warto zauważyć, iż w najnowszym opracowaniu dla danych za 2010 rok wśród ośrodków potencjalnych zostały wymienione: Kraków, Wrocław oraz Poznań (GAWC Research Data).

Istnieje wiele hierarchii i typologii miast zarówno na arenie światowej, europejskiej, jak i krajowej. Można jednak założyć, że nie ma idealnej typologii i kompletnego zestawu wskaźników, które w sposób całościowy opisywałyby poziom powiązań globalnych. Wychodząc z tego założenia, opracowano syntetyczną typologię na podstawie innych typologii dla ośrodków zlokalizowanych w krajach Unii Europejskiej (Raźniak, 2012b). Wzięto w niej pod uwagę zarówno stopień powiązań międzynarodowych (GAWC Research Data), obecność przemysłu high-tech (Krätke, 2007), badania ESPON-u (ESPON Atlas, 2006), jak i członkostwo w organizacjach międzynarodowych zrzeszających metropolie europejskie (METREX, 2000). Każdy ośrodek mógł zdobyć maksymalnie 17 punktów, które zostały przyznane w następujący sposób:

- miejsce w hierarchii METREX (2000): typ międzynarodowych centrów miejskich 3 punkty, typ europejskich centrów miejskich - 2 punkty, typ krajowych centrów miejskich -1 punkt; 


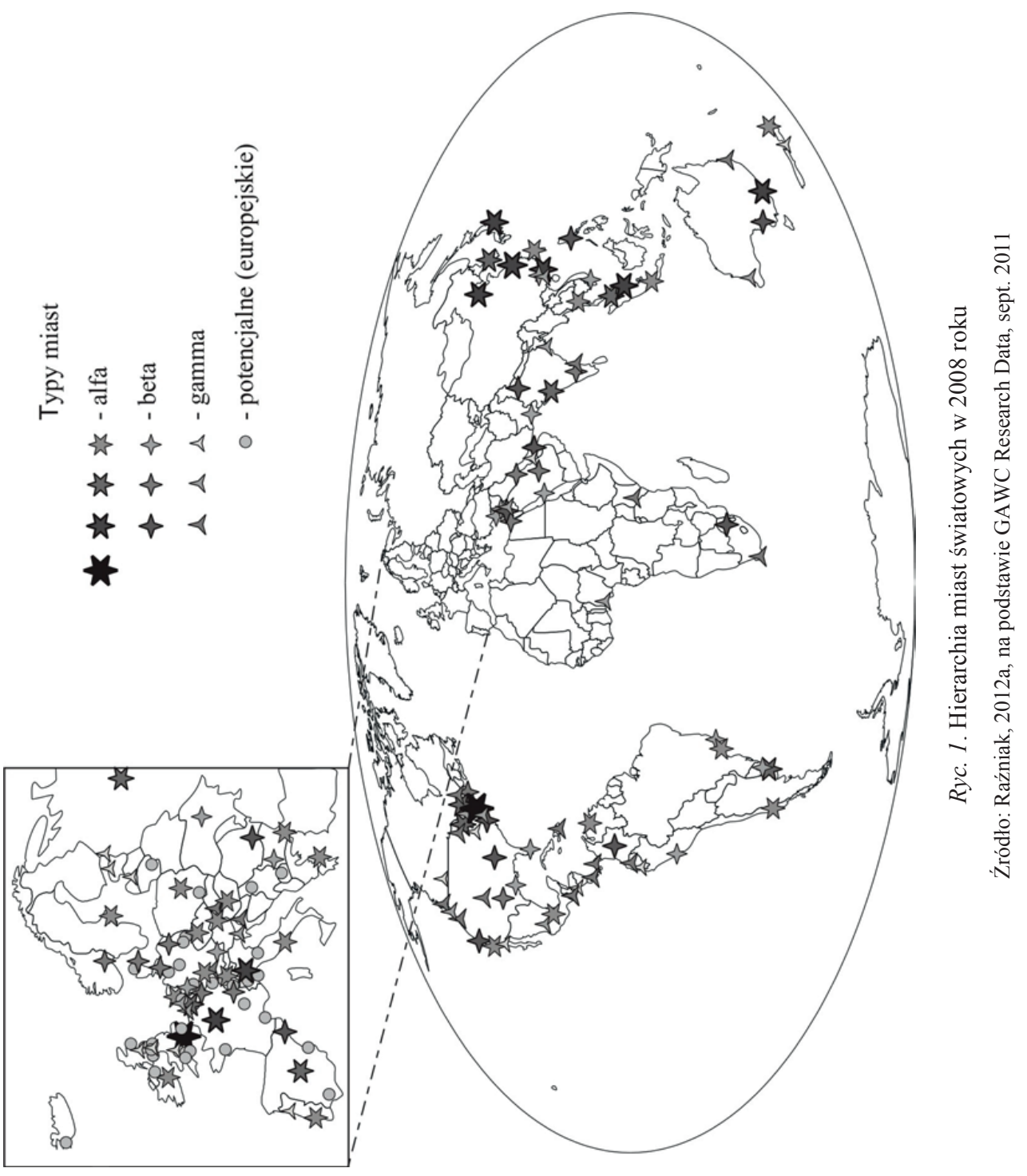


- miejsce w hierarchii ESPON (2006): typ globalnych i europejskich centrów wzrostu -4 punkty, silne MEGA - 3 punkty, potencjalne MEGA - 2 punkty, słabe MEGA - 1 punkt;

- miejsce w hierarchii S. Krätkego (2007): pierwsza kategoria - 4 punkty, druga - 3 punkty, trzecia - 2 punkty, czwarta i piąta - 1 punkt;

- miejsce w hierarchii GAWC (GAWC Research Data): typ alfa - 6 punktów, beta -4 punkty, gamma -2 punkty, potencjalne -1 punkt.

Ostatniej typologii nadano większą wagę, ponieważ określa ona międzynarodowe powiązania ponad 270 miast z całego świata, więc zdecydowano, iż wysokie miejsce w skali światowej powinno mieć większą wagę niż w skali kontynentalnej. W drugim i trzecim przypadku można było uzyskać maksymalnie 4 punkty, ponieważ obydwa biorą pod uwagę ośrodki europejskie. Z kolei opracowanie stowarzyszenia METREX jest najstarsze i od czasu jego powstania globalne powiązania mogły ulec zmianie; ponadto wyróżniono tam trzy typy metropolii. Biorąc pod uwagę wyżej wymienione aspekty, określono, iż maksymalna liczba punktów, jaką może otrzymać metropolia, to 3. Po zsumowaniu punktów otrzymano syntetyczną typologię metropolii obejmującą 27 krajów Unii Europejskiej.

Tab. 1. Syntetyczna typologia metropolii europejskich

\begin{tabular}{|c|c|c|}
\hline Typy miast & pkt & Miasto \\
\hline \multirow{3}{*}{$\begin{array}{l}\text { metropolie } \\
\text { globalne }\end{array}$} & 17 & Londyn, Paryż \\
\hline & 16 & Frankfurt, Madryt, Mediolan, Rzym \\
\hline & 14 & Barcelona, Berlin, Düsseldorf, Monachium, Sztokholm, Wiedeń \\
\hline \multirow{3}{*}{$\begin{array}{l}\text { metropolie } \\
\text { europejskie }\end{array}$} & 13 & Amsterdam, Bruksela, Budapeszt, Dublin, Hamburg, Kopenhaga, Warszawa \\
\hline & 12 & Ateny, Praga, Zurych \\
\hline & 11 & Lizbona \\
\hline \multirow{4}{*}{$\begin{array}{l}\text { metropolie } \\
\text { subkonty- } \\
\text { nentalne }\end{array}$} & 9 & Genewa, Helsinki, Lyon, Manchester \\
\hline & 8 & Oslo, Stuttgart, Turyn \\
\hline & 7 & Bukareszt, Marsylia \\
\hline & 6 & Birmingham, Bratysława, Hannover, Rotterdam, Sofia \\
\hline \multirow{4}{*}{$\begin{array}{l}\text { metropolie } \\
\text { potencjalne }\end{array}$} & 5 & Bilbao, Goeteborg, Luksemburg, Kolonia, Nantes, Neapol, Sewilla, Tallin, Tuluza \\
\hline & 4 & $\begin{array}{l}\text { Bolonia, Bordeaux, Edynburg, Florencja, Glasgow, Katowice, Kraków, Ljubljana, } \\
\text { Nikozja, Norymberga, Porto, Ryga, Wilno }\end{array}$ \\
\hline & 3 & Aarchus, Drezno, Genua, Lipsk, Lille, Łódź, Poznań, Strasburg, Walencja \\
\hline & 2 & $\begin{array}{l}\text { Alicante, Antwerpia, Brema, Cannes, Eindhoven, Gdańsk, Malmö, Newcastle, } \\
\text { Palermo, Palma de Mallorca, Reykjavik, Szczecin, Timiszoara, Wrocław, Zagrzeb }\end{array}$ \\
\hline $\begin{array}{l}\text { miasta } \\
\text { pozostałe }\end{array}$ & 1 & $\begin{array}{l}\text { Aberdeen, Bazylea, Belfast, Braszów, Bristol, Cardiff, Cork, Debreczyn, Dijon, } \\
\text { Edmonton, Halifax, Hawr, Leeds, Liverpool, Malaga, Metz, Portsmouth, Preszów, } \\
\text { Rochester, Saragossa, Seged, Southampton, Saloniki, Trevisio, Turku, Utrecht }\end{array}$ \\
\hline
\end{tabular}

Źródło: opracowanie własne na podstawie: METREX, 2000; ESPON Atlas, 2006; Krätke S., 2007; GAWC Research Data 
W zależności od otrzymanych punktów miasta podzielono na: metropolie globalne 14-17 pkt, metropolie europejskie 10-13 pkt, metropolie subkontynentalne 6-9 pkt, metropolie potencjalne 2-5 pkt, miasta pozostałe $1 \mathrm{pkt}$ (tab. 1). W systemie miast europejskich jedynie Londyn i Paryż uzyskały maksymalną liczbę punktów, ponadto do metropolii globalnych zaliczono jeszcze: Rzym, Mediolan, Madryt, Frankfurt, Wiedeń, Sztokholm, Monachium, Düsseldorf, Berlin i Barcelonę. Wśród polskich miast zaznacza się zdecydowana przewaga Warszawy, która znalazła się w gronie miast o znaczeniu europejskim (13 pkt). Sześć innych miast sklasyfikowanych zostało jako typ metropolii potencjalnych; Kraków i Katowice (4 pkt), Poznań i Łódź (3 pkt), natomiast Wrocław i Gdańsk po 2 punkty. Pozostałe miasta nie były uwzględnione w żadnym branym pod uwagę opracowaniu, co świadczy o ich niewielkich powiązaniach międzynarodowych.

\section{MIĘDZYNARODOWY RUCH TURYSTYCZNY W POLSKICH MIASTACH WOJEWÓDZKICH}

Dane dotyczące ruchu turystycznego i poziomu usług turystycznych zostały przedstawione w wartościach bezwzględnych. Można wyjść z założenia, iż podmioty planujące zorganizowanie konferencji, zjazdu, sympozjum, czy też szkolenia, są zainteresowane istniejącą ofertą w danym miejscu, jej dostępnością w określonym czasie, a nie wartościami względnymi przeliczanymi np. na 1000 mieszkańców danego miasta. Również we wcześniej omówionych hierarchiach miast światowych autorzy zagraniczni badali liczbę danych firm oraz faktyczne powiązania ośrodków bez uwzględniania ich potencjału demograficznego. $\mathrm{Z}$ pozycji międzynarodowego ruchu turystycznego takie podejście również wydaje się zasadne.

Zdecydowanie najpopularniejszymi miastami odwiedzanymi przez turystów z zagranicy są Kraków i Warszawa (tab. 2). W 2011 roku w stolicy kraju przenocowało 899,6 tysięcy osób. Na drugim miejscu znalazł się Kraków, jednak w latach 2006 i 2007 przyciągnął więcej osób z zagranicy niż Warszawa, która jest głównym polskim ośrodkiem usługowym, finansowym i handlowym (Burger, Knaap, Wall, 2012). Na kolejnych miejscach w zestawieniu ulokowały się Wrocław i Trójmiasto, jednak trzeba podkreślić, iż analizowane wartości były około czterokrotnie mniejsze niż w przypadku Warszawy i Krakowa. Należy zauważyć, iż tylko w 7 ośrodkach nocowało ponad 100 tysięcy turystów zagranicznych, a w przypadku najsłabszych wartość ta nie przekraczała 20 tysięcy. Należy zwrócić tutaj uwagę na konurbację katowicką, która mimo iż liczy około 2 milionów mieszkańców i ma wykształcone funkcje metropolitalne (Zuzańska-Żyśko, 2012), przyciąga jedynie około 120 tysięcy turystów zagranicznych. 
Tab. 2. Turyści zagraniczni korzystający z noclegów (w tys.)

\begin{tabular}{|l|r|r|r|r|r|r|r|c|}
\hline \multicolumn{1}{|c|}{ Miasto/rok } & 2005 & 2006 & 2007 & 2008 & 2009 & 2010 & 2011 & $\begin{array}{c}\text { Dynamika } \\
\text { W \% } \\
(2005-2011)\end{array}$ \\
\hline Warszawa & 744,4 & 732,8 & 746,8 & 764,5 & 752,5 & 833,3 & 899,6 & 20,9 \\
\hline Kraków & 731,8 & 770,8 & 820,0 & 684,1 & 688,9 & 770,2 & 805,7 & 10,1 \\
\hline Wrocław & 216,8 & 234,8 & 249,5 & 228,2 & 182,3 & 226,0 & 229,9 & 6,1 \\
\hline Trójmiasto & 219,8 & 217,5 & 214,5 & 185,2 & 198,6 & 205,7 & 224,7 & 2,2 \\
\hline Poznań & 165,6 & 168,1 & 157,0 & 159,5 & 153,5 & 163,1 & 150,8 & $-9,0$ \\
\hline Szczecin & 206,2 & 175,1 & 160,4 & 141,1 & 139,9 & 126,5 & 132,3 & $-35,8$ \\
\hline Kon. katowicka & 116,7 & 122,1 & 126,9 & 125,5 & 113,0 & 116,1 & 123,5 & 5,8 \\
\hline Łódź & 58,0 & 63,9 & 69,9 & 63,7 & 63,6 & 57,3 & 66,9 & 15,4 \\
\hline Lublin & 42,1 & 49,6 & 47,7 & 41,0 & 41,7 & 49,5 & 50,7 & 20,5 \\
\hline Toruń & 49,8 & 49,0 & 46,6 & 39,1 & 33,7 & 44,8 & 46,4 & $-6,9$ \\
\hline Toruń & 49,8 & 49,0 & 46,6 & 39,1 & 33,7 & 44,8 & 46,4 & $-6,9$ \\
\hline Białystok & 44,2 & 42,2 & 39,6 & 27,9 & 30,4 & 32,6 & 46,2 & 4,5 \\
\hline Rzeszów & 18,2 & 19,3 & 17,0 & 17,9 & 20,2 & 21,7 & 24,3 & 33,7 \\
\hline Olsztyn & 33,8 & 30,5 & 26,9 & 20,8 & 19,9 & 19,5 & 23,1 & $-31,5$ \\
\hline Bydgoszcz & 13,9 & 14,0 & 14,1 & 16,2 & 12,9 & 15,7 & 17,1 & 23,6 \\
\hline Gorzów Wlkp. & 18,4 & 18,2 & 18,5 & 16,0 & 10,1 & 10,8 & 13,2 & $-28,4$ \\
\hline Opole & 14,9 & 13,1 & 13,8 & 14,7 & 12,9 & 11,6 & 12,5 & $-15,7$ \\
\hline Kielce & 7,7 & 7,6 & 9,3 & 8,9 & 8,7 & 9,5 & 12,4 & 60,8 \\
\hline Zielona Góra & 12,5 & 12,2 & 14,4 & 12,4 & 8,9 & 7,2 & 10,1 & $-19,0$ \\
\hline & & & & & & & & \\
\hline Źro: & & & & & \\
\hline
\end{tabular}

Źródło: opracowanie własne na podstawie danych GUS

Z kolei w latach 2005-2011 najwyższą dynamikę liczby noclegów udzielonych zagranicznym turystom zaobserwowano w Kielcach $(+60,8 \%)$. Mimo to wartość wynosząca 12,4 tysiąca plasuje to miasto na przedostatniej pozycji. Stosunkowo wysokie wzrosty zanotowano w Warszawie i Krakowie, które równocześnie w XXI wieku znacząco rozwinęły powiązania międzynarodowe (Raźniak, 2012a). Może się to wiązać z kontaktami pomiędzy zagranicznymi siedzibami firm a ich oddziałami ulokowanymi w tych miastach. Pozostałe polskie metropolie potencjalne również charakteryzowały się wzrostem międzynarodowego ruchu turystycznego. Wyjątkiem był tutaj Poznań, w którym wystąpił 9\% spadek przyjazdów. Spowodowane mogło to być utrzymującym się wysokim ujemnym saldem migracji ludności w mieście i wysokim dodatnim saldem migracji w powiecie poznańskim (Winiarczyk-Raźniak, Raźniak, 2012), które jednocześnie jest areną dynamicznych inwestycji firm (Raźniak 2013). Podróżujący służbowo mogą przez to wybierać noclegi w strefie podmiejskiej, co pozwala skrócić czas dojazdu do miejsca docelowego. Ponadto dużymi spadkami charakteryzowały się Gorzów Wielkopolski i Zielona Góra, które są stolicami województwa lubuskiego, cechującego się wysokim udziałem firm z kapitałem zagranicznym (Gorzelak, Jałowiecki, Smętkowski, 2009). Do mniejszej liczby przyjeżdżających z zagranicy mogło się 
też przyczynić dobre skomunikowanie tych miast z Niemcami, które są głównym partnerem handlowym Polski. Stosunkowo niewielkie odległości pozwalają na realizację celów służbowych w ciągu jednego dnia, bez konieczności nocowania w tych miastach.

\section{LICZBA OBIEKTÓW NOCLEGOWYCH}

Analizując dynamikę zmian liczby obiektów noclegowych, wzięto pod uwagę hotele, motele, pensjonaty mające kategorię co najmniej $3^{*}$, wychodząc z założenia, że niższe kategorie nie są zbyt często wybierane w przypadku podróży biznesowych, konferencji naukowych itp. Wyższy standard może być brany pod uwagę ze względu na wizerunek międzynarodowych firm czy też uczelni. Interesująco przedstawia się dynamika zmian liczby obiektów noclegowych średniej i wyższej klasy w polskich miastach (ryc. 2). Zdecydowanie najwyższą dynamiką wykazał się Kraków.

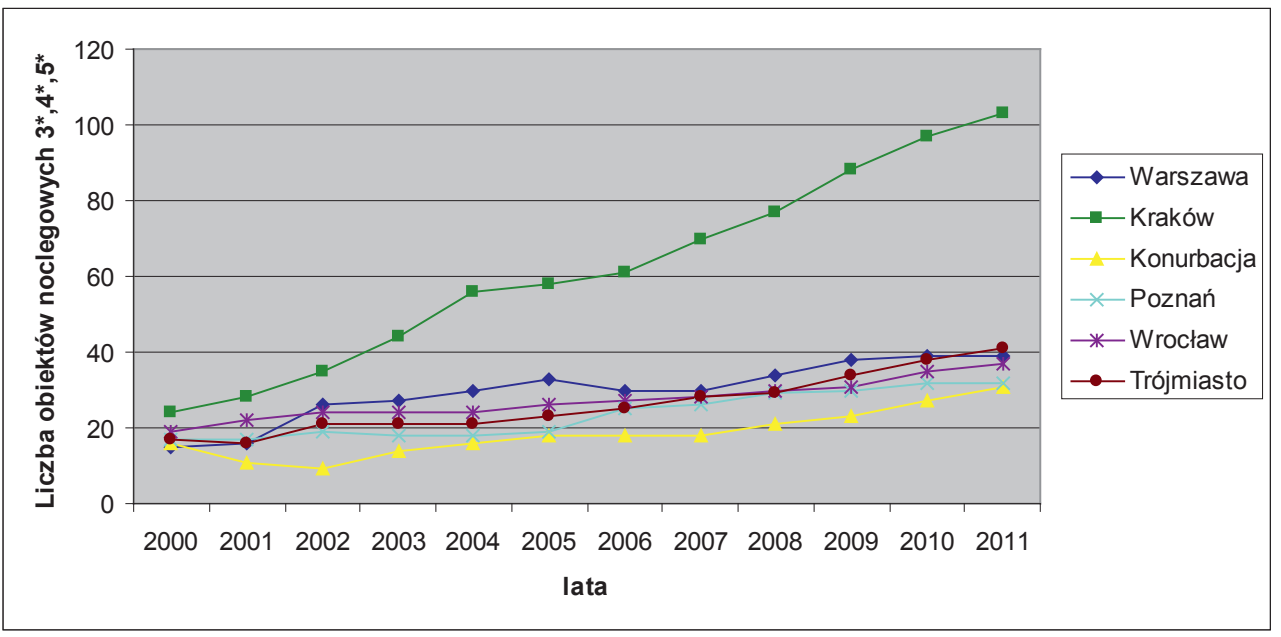

Ryc. 2. Zmiany liczby obiektów noclegowych kategorii 3*, 4* i 5*

Źródło: opracowanie własne na podstawie danych GUS

Ośrodki przedstawione na ryc. 2 dysponują największą spośród miast wojewódzkich liczbą obiektów noclegowych zaliczonych do średniej i wyższej klasy. Znajdujące się na kolejnych miejscach Rzeszów i Toruń miały jedynie po 13 obiektów noclegowych o klasie 3* i wyższej. Należy także zwrócić uwagę na Łódź, która mimo dużej liczby mieszkańców dysponowała w 2011 roku tylko 12 takimi obiektami. Mała atrakcyjność miasta może wynikać z niewielkiej liczby miejsc wartych obejrzenia w porównaniu do innych miast w kraju. Również pobliska Warszawa może być konkurencją dla biznesu, który chętniej lokuje się w stolicy niż w Łodzi. Oddziaływanie Warszawy może wpływać na stosunkowo niski 
współczynnik zatrudnienia w sektorach wysokich technologii i wiedzochłonnych (Kurek, 2010), wobec czego zapotrzebowanie na usługi hotelowe jest stosunkowo niewielkie.

\section{WYPOSAŻENIE OBIEKTÓW NOCLEGOWYCH W USŁUGI}

Dla firm i instytucji poszukujących lokalizacji dla spotkań ważna jest nie tylko dostępność obiektów określonej kategorii w określonym czasie, ale również możliwość korzystania z odpowiednich usług. W przypadku organizacji spotkań biznesowych, szkoleń, konferencji itp. bardzo ważna jest możliwość wynajęcia sal konferencyjnych i odpowiedniego sprzętu niezbędnego do prowadzenia prezentacji multimedialnych. Wzięto pod uwagę 11 kategorii usług związanych z zapleczem konferencyjnym. Były to:

- sala konferencyjna;

- liczba sal konferencyjnych;

- liczba miejsc w salach konferencyjnych;

- nagłośnienie;

- mikrofon bezprzewodowy;

- komputer;

- zestaw audio-wideo;

- obsługa techniczna;

- ekran;

- flipchart;

- rzutnik/projektor.

Jest to podstawowe wyposażenie, bez którego organizacja większych spotkań biznesowych lub naukowych jest praktycznie niemożliwa. Aby określić miejsce w hierarchii miast, zastosowano metodę rang. Miasto dysponujące najbardziej rozbudowanym wyposażeniem w danej kategorii otrzymywało 18 pkt, drugie - 17 pkt, a ostatnie odpowiednio 1 pkt. Badanie powtórzono dla każdej z 11 cech, konstruując hierarchię miast pod względem poziomu wyposażenia w usługi konferencyjne. Maksymalnie ośrodek mógł uzyskać 198 pkt (18 pkt razy 11 cech), natomiast minimalna wartość to 11 (1 pkt razy 11 cech).

Tab. 3. Hierarchia miast wg poziomu wyposażenia obiektów noclegowych

\begin{tabular}{|c|l|c|}
\hline Lp. & \multicolumn{1}{|c|}{ Ośrodek } & Pkt \\
\hline 1 & Kraków & 196 \\
\hline 2 & Warszawa & 185 \\
\hline 3 & Trójmiasto & 180 \\
\hline 4 & Poznań & 165 \\
\hline 5 & Konurbacja katowicka & 152 \\
\hline 6 & Wrocław & 145 \\
\hline 7 & Lódź & 132 \\
\hline
\end{tabular}




\begin{tabular}{|c|l|c|}
\hline 8 & Szczecin & 118 \\
\hline 9 & Toruń & 100 \\
\hline 10 & Bydgoszcz & 96 \\
\hline 11 & Kielce & 91 \\
\hline 12 & Lublin & 71 \\
\hline 13 & Olsztyn & 56 \\
\hline 14 & Rzeszów & 56 \\
\hline 15 & Białystok & 51 \\
\hline 16 & Zielona Góra & 50 \\
\hline 17 & Opole & 25 \\
\hline 18 & Gorzów Wielkopolski & 12 \\
\hline
\end{tabular}

Źródło: opracowanie własne na podstawie danych GUS

Ze zdecydowanie najlepszym wyposażeniem mamy do czynienia w obiektach noclegowych w Krakowie, który zdobył 196 punktów na 198 możliwych. Jedynie w przypadku liczby sal konferencyjnych i liczby miejsc w salach konferencyjnych został wyprzedzony przez Warszawę. Na kolejnych miejscach znalazły się Trójmiasto i Poznań. Należy zauważyć, iż Łódź również pod względem wyposażenia w usługi hotelowe jest na ostatnim siódmym miejscu spośród ośrodków miejskich liczących ponad 500 tysięcy mieszkańców. Z kolei na ostatnich miejscach sklasyfikowano miasta położone na wchodzie Polski, co może się wiązać z ich znacznie niższą pozycją gospodarczą oraz słabszą wymianą handlową z krajami za wschodnią granicą, niż w odniesieniu do ośrodków położonych na zachodzie kraju. Odmienne przyczyny mogły zaistnieć w przypadku położonych na zachodzie kraju Gorzowa Wielkopolskiego, Zielonej Góry i Opola. Tutaj bliskość granicy zachodniej i dobra komunikacja mogą dawać możliwość załatwienia spraw służbowych w ciągu jednego dnia, zwłaszcza biorąc pod uwagę, iż na pierwszym miejscu pod względem przyjazdów biznesowych do Polski są Niemcy.

\section{SYNTETYCZNY RANKING POD WZGLĘDEM POZIOMU USŁUG}

\section{INFRASTRUKTURY NOCLEGOWEJ}

Dla syntetycznego porównania miast pod względem poziomu infrastruktury noclegowej i usług turystycznych stworzono ranking, w którym wzięto pod uwagę te cechy, które mogą przyczynić się do rozwoju powiązań międzynarodowych miast. Są to:

- liczba turystów zagranicznych korzystających z noclegów w 2011 roku;

- liczba obiektów noclegowych 3*, 4* i 5* w 2011 roku;

- wyposażenie obiektów noclegowych w 2009 roku (dane są dostępne tylko dla roku 2009). 
Tab. 4. Ranking miast pod względem infrastruktury i usług turystycznych

\begin{tabular}{|c|c|c|c|c|c|}
\hline Miejsce & Miasto/hierarchia & $\begin{array}{c}\text { Liczba turystów } \\
\text { zagranicznych } \\
\text { korzystających } \\
\text { z noclegów w } 2011 \mathrm{r} \text {. }\end{array}$ & $\begin{array}{l}\text { Liczba obiektów } \\
\text { noclegowych } 3^{*}, \\
4^{*} \text { i 5* w } 2011 \mathrm{r} \text {. }\end{array}$ & $\begin{array}{l}\text { Wyposażenie } \\
\text { obiektów } \\
\text { noclegowych } \\
\text { w } 2009 \text { r. }\end{array}$ & $\begin{array}{c}\text { Ranking } \\
\text { syntetyczny }\end{array}$ \\
\hline 1 & Kraków & 17 & 18 & 18 & 53 \\
\hline 2 & Warszawa & 18 & 16 & 17 & 51 \\
\hline 3 & Trójmiasto & 15 & 17 & 16 & 48 \\
\hline 4 & Wrocław & 16 & 15 & 13 & 44 \\
\hline 5 & Poznań & 14 & 14 & 15 & 43 \\
\hline 6 & Kon. katowicka & 12 & 13 & 14 & 39 \\
\hline 7 & Łódź & 11 & 10 & 12 & 33 \\
\hline 7 & Szczecin & 13 & 9 & 11 & 33 \\
\hline 9 & Toruń & 9 & 12 & 10 & 31 \\
\hline 10 & Lublin & 10 & 8 & 7 & 25 \\
\hline 11 & Rzeszów & 7 & 12 & 5 & 24 \\
\hline 12 & Bydgoszcz & 5 & 6 & 9 & 20 \\
\hline 13 & Kielce & 2 & 8 & 8 & 18 \\
\hline 14 & Olsztyn & 6 & 5 & 6 & 17 \\
\hline 15 & Białystok & 8 & 2 & 4 & 14 \\
\hline 16 & Opole & 3 & 4 & 2 & 9 \\
\hline 17 & Zielona Góra & 1 & 4 & 3 & 8 \\
\hline 18 & Gorzów Wlkp. & 4 & 2 & 1 & 7 \\
\hline
\end{tabular}

Źródło: opracowanie własne na podstawie danych GUS

W każdym przypadku ośrodek mógł otrzymać maksymalnie 18 punktów (za pierwsze miejsce), natomiast ostatnie wiązało się z przyznaniem 1 punktu. Łącznie można było uzyskać 54 pkt (3x18), minimalnie 3 pkt (3x1). Najwyższym poziomem wyposażenia i usług turystycznych cechuje się Kraków, który zgromadził 53 pkt (na 54 możliwe). Na kolejnych miejscach z kilkupunktową stratą sklasyfikowano Warszawę, Trójmiasto i Wrocław (tab. 4). Należy zwrócić uwagę na Kielce, sklasyfikowane na 13 miejscu, które mają stosunkowo dobry poziom infrastruktury i usług turystycznych, jednak pod względem liczby odwiedzających turystów zagranicznych plasują się na przedostatniej pozycji. Można sądzić, iż miasto jest odwiedzane przez osoby pochodzące z Polski, natomiast słaby rozwój funkcji międzynarodowych powoduje niewielkie zainteresowanie osób przybywających z innych krajów. Odmienna sytuacja ma miejsce w Białymstoku, gdzie słaba infrastruktura turystyczna nie przeszkadza w uzyskaniu stosunkowo wysokiego miejsca pod względem liczby przyjezdnych z zagranicy. Przyczyną może być bliskość granicy ze wschodnimi sąsiadami, w tym z Białorusią, a zwłaszcza z Litwą należącą do Unii Europejskiej. 


\section{USŁUGI I INFRASTRUKTURA TURYSTYCZNA}

A POZIOM POWIĄZAŃ MIĘDZYNARODOWYCH

W kolejnym zestawieniu porównano miejsca zajmowane w rankingu miast pod względem infrastruktury i usług turystycznych z miejscem w hierarchiach miast światowych, europejskich, a także poziom rozwoju społeczno-gospodarczego na arenie krajowej (tab. 5). W opracowaniach światowych pojawiają się jedynie 4 polskie miasta cechujące się wysokim poziomem rozwoju ekonomicznego (Bogdański, 2012), z których tylko Warszawa jest zaliczana do ośrodków o silnych powiązaniach gospodarczych w skali międzynarodowej (Taylor, Hoyler, Sánchez-Moral, 2012; Taylor, 2012). Natomiast Wrocław, Kraków i Poznań są miastami o słabo wykształconych powiązaniach globalnych (GAWC Research Data). Można zauważyć, iż Kraków ma wyższy potencjał związany z zapleczem turystycznym, niż wynika to z powiązań międzynarodowych, natomiast Warszawa, Wrocław i Poznań zajęły wyższe miejsca w opracowaniach dotyczących powiązań globalnych niż w rankingu syntetycznym. Z kolei w hierarchii miast europejskich (Raźniak, 2012b) znalazło się tylko 7 ośrodków, spośród których jedynie Trójmiasto dysponuje zdecydowanie lepiej rozwiniętą infrastrukturą i usługami noclegowymi w porównaniu do miejsca wśród miast europejskich. Może wiązać się to z rozwiniętą funkcją turystyczną tej konurbacji, która przyciąga znaczną liczbę wczasowiczów odpoczywających nad Bałtykiem. Miejsce konurbacji katowickiej i Łodzi w hierarchii europejskiej nie przekłada się na istniejący tam poziom usług turystycznych, co może być związane z małą atrakcyjnością tych ośrodków dla turystów zagranicznych ze względu na zdegradowany krajobraz i środowisko. Ponadto w przypadku Łodzi powodem niskiego miejsca w rankingu syntetycznym mógł być również kryzys branży włókienniczej z lat 90. XX wieku (Suliborski, Wójcik, Walkiewicz, 2010), która związana była głównie z rynkiem dawnego Związku Radzieckiego (Jakóbczyk-Gryszkiewicz, 2011). $\mathrm{Z}$ kolei porównanie syntetycznego rankingu i hierarchii biorącej pod uwagę poziom rozwoju społeczno-gospodarczego ośrodków wojewódzkich wykazuje dużą zbieżność zajmowanych miejsc (Jałowiecki, 2006). Generalnie różnica w pozycjach miast, istniejąca pomiędzy tymi zestawieniami, nie przekraczała 3 miejsc. Jedynie w przypadku Torunia zauważono różnicę 9 pozycji (9 w rankingu syntetycznym, 18 w hierarchii B. Jałowieckiego). Niski poziom rozwoju społeczno-gospodarczego w tym przypadku jest rekompensowany przez wysokie walory kulturowe miasta, które przekładają się na rozwinięte usługi turystyczne. Jednak brak Torunia w hierarchiach i typologiach międzynarodowych pokazuje jego słabe oddziaływanie ponadkrajowe. Można stwierdzić, iż poziom oferty usług i infrastruktury turystycznej jest skorelowany z miejscem miast w hierarchiach opracowywanych zarówno w aspekcie globalnym, kontynentalnym, jak też na arenie krajowej. 
Tab. 5. Poziom rozwoju infrastruktury i usług turystycznych

a poziom rozwoju społeczno-gospodarczego miast

\begin{tabular}{|l|c|c|c|c|c|c|c|}
\hline Miasto/ranking & $\begin{array}{c}\text { Miejsce } \\
\text { w rankingu } \\
\text { syntetycznym } \\
\text { (tab. 4) }\end{array}$ & $\begin{array}{c}\text { Hierarchia } \\
\text { miast świa- } \\
\text { towych } \\
\text { w 2010 r. }\end{array}$ & $\begin{array}{c}\text { Różnica } \\
\text { w ran- } \\
\text { kingu* }\end{array}$ & $\begin{array}{c}\text { Hierarchia } \\
\text { metropolii } \\
\text { europej- } \\
\text { skich }\end{array}$ & $\begin{array}{c}\text { Różnica } \\
\text { w ran- } \\
\text { kingu* }\end{array}$ & $\begin{array}{c}\text { Jałowiecki, } \\
2006\end{array}$ & $\begin{array}{c}\text { Różnica } \\
\text { w ran- } \\
\text { kingu* }\end{array}$ \\
\hline Kraków & 1 & 3 & 2 & 2 & 1 & 4 & 3 \\
\hline Warszawa & 2 & 1 & -1 & 1 & -1 & 1 & -1 \\
\hline Trójmiasto & 3 & - & - & 7 & 4 & 5 & 2 \\
\hline Wrocław & 4 & 2 & -2 & 6 & 2 & 3 & -1 \\
\hline Poznań & 5 & 4 & -1 & 4 & -1 & 2 & -3 \\
\hline Kon. katowicka & 6 & - & - & 3 & -3 & 6 & 0 \\
\hline Łódź & 7 & - & - & 5 & -2 & 7 & 0 \\
\hline Szczecin & 8 & - & - & - & - & 8 & 0 \\
\hline Toruń & 9 & - & - & - & - & 18 & 9 \\
\hline Lublin & 10 & - & - & - & - & 9 & -1 \\
\hline Rzeszów & 11 & - & - & - & - & 14 & 3 \\
\hline Bydgoszcz & 12 & - & - & - & - & 11 & -1 \\
\hline Kielce & 13 & - & - & - & - & 10 & -3 \\
\hline Olsztyn & 14 & - & - & - & - & 15 & 1 \\
\hline Białystok & 15 & - & - & - & - & 12 & -3 \\
\hline Opole & 16 & - & - & - & - & 13 & -3 \\
\hline Zielona Góra & 17 & - & - & - & - & 16 & -1 \\
\hline Gorzów Wlkp. & 18 & - & - & - & - & 17 & -1 \\
\hline
\end{tabular}

${ }^{*}$ Różnica miejsc w stosunku do miejsca w rankingu syntetycznym (tab. 4).

Źródło: opracowanie własne na podstawie danych GUS, GAWC Research Data; Raźniak, 2013; Jałowiecki, 2006

\section{Podsumowanie}

Mamy do czynienia ze zdecydowaną przewagą napływu turystów międzynarodowych do Warszawy i Krakowa, natomiast kolejne ośrodki dzieli kilkukrotna różnica pod względem liczby przybywających z zagranicy. Również te dwa miasta mają najlepiej rozwiniętą infrastrukturę noclegową średniej i wyższej klasy oraz największą dostępność usług związanych z możliwością zorganizowania konferencji, szkolenia czy też spotkania z partnerami biznesowymi. Rozwój omawianej infrastruktury może zachęcić potencjalnych inwestorów lub firmy do inwestowania w tych ośrodkach. Biorąc pod uwagę, zwłaszcza w przypadku Warszawy, silne powiązania międzynarodowe, można założyć, iż rozwój infrastruktury hotelowej może przyczyniać się do wzmocnienia powiązań globalnych. Zauważono słaby poziom omawianych usług w miastach położonych na wschodzie Polski, co może wiązać się z mniejszymi powiązaniami gospodarczymi Polski z krajami wschodnimi, w porównaniu do 
powiązań z państwami Unii Europejskiej. Z drugiej strony korzystne położenie pod względem komunikacyjnym Gorzowa Wielkopolskiego i Zielonej Góry powoduje, iż wiele spraw służbowych pracownicy niemieccy mogą zrealizować w ciągu dnia i wrócić na noc do kraju. Może to przejawiać się w bardzo słabym rozwoju infrastruktury i usług nastawionych na partnerów biznesowych i instytucjonalnych w tych miastach. Z kolei zauważono korelację pomiędzy miejscem w międzynarodowych hierarchiach miast a poziomem rozwoju bazy noclegowej. Polskie ośrodki najwyżej sklasyfikowane w hierarchiach międzynarodowych miały generalnie najlepiej rozwiniętą bazę noclegową średniej i wyższej klasy oraz oferowały szeroki wachlarz usług związanych z organizacją spotkań biznesowych i konferencji. Należy zauważyć, iż nie ma bezpośredniego związku pomiędzy liczbą ludności danego ośrodka a liczbą turystów zagranicznych odwiedzających dane miasto, czy też poziomem rozwoju infrastruktury i usług turystycznych.

\section{Literatura}

Bartoszewicz, W., Borne-Januła, H., Buczak, T., Skalska, T., Socjała J. (2003). Metodologia badań i badania pilotażowe turystyki biznesowej. Warszawa: Instytut Turystyki.

Beaverstock, J.V, Smith, R.G., Taylor, P.J. (1999). A Rooster of World Cities. Cities, 6(6), 445-458.

Bogdański, M. (2012). Socio-economic Potential of Polish Cities - a Regional Dimension. Bulletin of Geography Socio-economic Series, 17, 13-20.

Burger, J.M., Knaap B. van der, Wall, R.S. (2012). Revealed Competition for Greenfield Investment in European Regions. Journal of Economic Geography, published September 2012 (online).

METREX - European Metropolitan Regions and Areas (2000). www.eurometrex.org/EN/index.asp

ESPON Atlas. (2006). Mapping the Structure of the European Territory. Federal Office for Building and Regional Planning.

GAWC Research Data, http://www.lboro.ac.uk/gawc.

Główny Urząd Statystyczny, www.stat.gov.pl.

Gorzelak, G., Jałowiecki, B., Smętkowski, M. (red.). (2009). Obszary Metropolitalne w Polsce: problemy rozwojowe i delimitacja. Raporty i analizy EUROREG 1/2009, Warszawa.

Jakóbczyk-Gryszkiewicz, J. (2011). Łódź u progu XX wieku. Studia Miejskie, nr 4, Opole, 131-138.

Jałowiecki, B. (red.). (2006). Uwarunkowania i szanse rozwoju polskich metropolii. Warszawa: Departament Koordynacji Polityki Strukturalnej MGPiPS.

Krätke, S. (2007). Metropolisation of the European Economic Territory as a Consequence of Increasing Specialisation of Urban Agglomerations in the Knowledge Economy. European Planning Studies, $15,1-27$.

Kulbaczewska, M., Kubicki, R. (2007). Analiza ruchu turystycznego w zakładach uzdrowiskowych na tle obiektów noclegowych ogółem w województwie zachodniopomorskim w latach 2001-2005. Zeszyty Naukowe, 466, Uniwersytet Szczeciński.

Kulesza, I. (red.). (2008). Turystyka biznesowa w Polsce. Warszawa: Instytut Turystyki.

Kurek, S. (2010). Przestrzenne zróżnicowanie poziomu rozwoju regionalnego w Unii Europejskiej w świetle wybranych mierników. Prace Komisji Geografii Przemystu Polskiego Towarzystwa Geograficznego, 16, 87-104.

Kłębek, K. (red.). (2009). Turystyka biznesowa w Polsce. Kraków: AWF.

Michalak, Z., Warzocha, J. (2007). Turystyka biznesowa jako produkt łagodzący skutki sezonowości w działalności hotelarskiej. Zeszyty Naukowe, 466, Uniwersytet Szczeciński.

Nowakowska, A. (2002). Turystyka, turysta, ruch turystyczny. W: G. Gołembski (red.). Kompedium wiedzy o turystyce. Warszawa-Poznań: PWN, 191-196. 
Raźniak, P. (2012a). Procesy społeczno-ekonomiczne w Krakowskim Obszarze Metropolitalnym. Prace Geograficzne Uniwersytetu Jagiellońskiego, 129, 63-81.

Raźniak, P. (2012b). Global Connections of European Metropolises - an Attempt to Typology, Multikulturalis Muhely, 2, 102-108.

Raźniak, P. (2013). Globalne powiązania metropolii europejskich - próba typologii. Studia Miejskie, 9, 83-94.

Suliborski, A., Wójcik, M., Walkiewicz, D. (2010). Funkcje i struktura funkcjonalna Łódzkiego Obszaru Metropolitalnego. W: A. Jewtuchowicz, M. Wójcik (red.). Łódzka Metropolia-Problemy integracji Gospodarczej, Łódź, 21-40.

Szymańska, A.I. (2012a). User-driven Innovation - a Consumer as a Source of Innovation in the Enterproise. W: K. Zawadzki (red.). Challenges for the SME Sector in the Twenty-first Century, Gdańsk, Politechnika Gdańska, Wydział Zarządzania i Ekonomii, 58-67.

Szymańska, A.I. (2012b). User-driven Innovation (UDI) - nowe podejście do innowacji a preferencje konsumentów. W: R. Pukała (red.). Zarządzanie podmiotami gospodarczymi i instytucjami. Wybrane zagadnienia. Jarosław: Wydawnictwo Państwowej Wyższej Szkoły Techniczno-Ekonomicznej im. ks. Bronisława Markiewicza w Jarosławiu, 9-31.

Szymańska, A.I. (2012c). Wpływ innowacyjności na konkurencyjność przedsiębiorstw. W: A. Stabryła, T. Małkus (red.). Strategie rozwoju organizacji, seria wydawnicza: Encyklopedia Zarządzania, Kraków, Mfiles.pl, 183-197.

Taylor, P.J., Hoyler, M., Sánchez-Moral, S. (2012). European Cities in Globalization: A Comparative Analysis Based on the Location Strategies of Advanced Producer Services. GAWC Research Bulletin, 416, http://www.lboro.ac.uk/gawc.

Taylor, P.J. (2012). The Challenge Fading World City Network Analysis. GaWC Research Bulletin, 409, http://www.lboro.ac.uk/gawc.

Taylor, P.J., Ni, P., Derudder, B., Hoyler, M., Huang, J., Lu, F., Pain, K., Witlox, F., Yang, X., Basens, D., Shen, W. (2010). Measuring the World City Network: New Results and Developments. GaWC Research Bulletin, 300, http://www.lboro.ac.uk/gawc.

Vijver, E. Van De, Derudder, B., Bassens, D., Witlox, F. (2012). Filling Some Black Holes: Modeling the Connection between Urbanization, Infrastructure, and Global Service Intensity. GAWC Research Bulletin, 396, http://www.lboro.ac.uk/gawc.

Winiarczyk-Raźniak, A., Raźniak, P. (2012). Migracje wewnętrzne ludności w polskich obszarach metropolitalnych u progu XXI wieku. Kraków: Wydawnictwo Naukowe UP.

Zdon-Korzeniowska, M., Rachwał, T. (2011). Turystyka w warunkach światowego kryzysu gospodarczego. Prace Komisji Geografii Przemystu Polskiego Towarzystwa Geograficznego, 18, 116-128.

Zuzańska-Żyśko, E. (2012). Funkcje metropolitalne Górnośląskiego Obszaru Metropolitalnego. Studia Regionalne i Lokalne, 2(48), 39-61.

Piotr Raźniak, dr, Uniwersytet Pedagogiczny w Krakowie, Instytut Geografii.

Pracownik Instytutu Geografii Uniwersytetu Pedagogicznego w Krakowie. Do zainteresowań badawczych należą hierarchie miast światowych, problemy funkcjonowania obszarów metropolitalnych oraz migracje ludności.

Piotr Raźniak, employee of the Institute of Geography of Pedagogic University in Kraków. Hierarchies of world cities, problems of functioning of metropolitan areas and migrations of the population are included in research interests.

adres/address: Uniwersytet Pedagogiczny w Krakowie

Instytut Geografii

ul. Podchorążych 2, 30-084 Kraków, Polska

e-mail: prazniak@afm.edu.pl 